\title{
RECENT ADVANCES IN PERSONAL PROTECTIVE EQUIPMENT USING NANOTECHNOLOGY AS A SHIELD AGAINST SARS-COV-2 ${ }^{1}$
}

\author{
AVANÇOS RECENTES EM EQUIPAMENTOS DE PROTEÇÃO INDIVIDUAL \\ USANDO NANOTECNOLOGIA COMO UM PROTETOR CONTRA SARS-COV-2
}

\author{
Giane Engel Montagner ${ }^{2}$, Aline Rossato ${ }^{3}$, Solange Binotto Fagan ${ }^{4}$ and Patrícia Gomes ${ }^{5}$
}

\begin{abstract}
COVID-19 is a disease caused by the SARS-CoV-2 coronavirus, and the use of personal protective equipment (PPE) has become essential against pandemics. This has led to many advances in facial masks and other types of PPE, using nanotechnology to improve antiviral properties and filterability. In this context, this study aimed at carrying out an integrative review regarding advances in personal protective equipment using nanotechnology to improve antiviral properties against SARS-CoV-2. Thus, 34 articles were retrieved from the Web of Science, Scopus, and PubMed databases, published until August 22, 2021. The main nanostructures used were nanofibers, carbon nanotubes, metallic nanoparticles, nanorods, nanowires, graphene, and C-dots, in the use of facial masks, air filters, and antiviral surfaces with functions such as antiviral/antimicrobial, reuse of personal protective equipment (PPE), self-feeding, whether by mechanical or solar action, hydrophobicity, and filtration efficiency, adjustable to the physical biotype of each individual and high breathability.
\end{abstract}

Keywords: Air filter, Antiviral, COVID-19, Mask, Nanostructure.

\section{RESUMO}

A COVID-19 é uma doença causada pelo coronavírus SARS-CoV-2, e o uso de equipamentos de proteção individual (EPI) tornou-se essencial contra as pandemias. Isso levou a muitos avanços em máscaras faciais e outros tipos de EPI, usando nanotecnologia para melhorar as propriedades antivirais e a filtrabilidade. Nesse contexto, o objetivo deste estudo foi realizar uma revisão integrativa a respeito dos avanços em equipamentos de proteção individual utilizando nanotecnologia para melhorar as propriedades antivirais contra SARSCoV-2. Assim, foram recuperados 34 artigos das bases de dados Web of Science, Scopus e PubMed, publicados até 22 de agosto de 2021. As principais nanoestruturas utilizadas foram nanofibras, nanotubos de carbono, nanopartículas metálicas, nanobastões, nanofios, grafeno e pontos $C$, em uso de máscaras faciais, filtros de ar e superficies antivirais com funções como antiviral / antimicrobiano, reaproveitamento de equipamentos de proteção individual (EPI), autoalimentação, seja por ação mecânica ou solar, hidrofobicidade e eficiência de filtração, ajustável ao biótipo físico de cada indivíduo e alta respirabilidade.

Palavras-chave: Antiviral, COVID-19, Filtro de ar, Máscara, Nanoestrutura.

1 Study performed at Postgraduate Program in Nanosciences.

2 PhD student - Postgraduate Program in Nanosciences - Universidade Franciscana. E-mail: giane.engel@gmail.com

3 PhD student - Postgraduate Program in Nanosciences - Universidade Franciscana. E-mail: alinerossato07@gmail.com

4 Contributor - Postgraduate Program in Nanosciences - Universidade Franciscana. E-mail: sfagan@ufn.edu.br

5 Contributor - Postgraduate Program in Nanosciences - Universidade Franciscana. E-mail: patriciagomes@ufn.edu.br 


\section{INTRODUCTION}

Viral infections are one of the main causes of morbidity and mortality and also of significant economic losses worldwide. Standard treatment approaches are mainly based on vaccination and therapy derived from key processes in the virus life cycle (WEISS et al., 2020). The newly emerged COVID-19 disease is a highly transmissible viral infection caused by another new zoonotic coronavirus called severe acute respiratory syndrome coronavirus 2 (SARS-CoV-2), first reported in December 2019 in a local seafood market in Wuhan, Hubei Province, China (KHAN et al., 2020).

SARS-CoV-2 is a large, positive-stranded, enveloped RNA virus with nucleocapsid and structure similar to SARS-CoV-1, its diameter size ranging from 80 to $140 \mathrm{~nm}$. This virus has become a leading cause of emerging respiratory diseases and has spread rapidly around the world, affecting billions of people and triggering unexpected changes in the healthcare system, global economy, and interactions in societies around the world (VAZQUEZ-MUNOZ; LOPEZ-RIBOT, 2020).

The World Health Organization (WHO) globally has reported as of September 23, 2021, more than 229 million confirmed cases of COVID-19 and 4.705.111 deaths (WHO, 2021). The costs related to this communicable disease are estimated to be in trillions of dollars globally, but the real cost cannot be estimated. Several measures have been implemented to control COVID-19, from campaigns aimed at improving personal hygiene practices to community approaches such as social distancing and quarantines (CARVALHO; CONTE-JUNIOR, 2021). As a result, there has been a great demand for designing tools to improve antiviral strategies to control the spread of COVID-19, such as advances in the design of facial masks, and other types of personal protective equipment (PPE) such as gloves, lab coats and clothing. The COVID-19 outbreak has clearly shown the need for substantial PPE development using multifunctional materials with antiviral properties (KARAGOZ et al., 2021).

Viruses are considered naturally occurring nanoparticles due to their nanometric size. Thus, because of the small size and adjustable surface charge, nanoscale materials have great potential to interact with the peak protein to block the onset of viral infection (CARVALHO; CONTE-JUNIOR, 2021). Nanomaterials are single structures, free or in a compound, with size within the nanometer range, usually less than $100 \mathrm{~nm}$ in at least one of its three dimensions. Within the nanometer range, the physicochemical properties of materials exhibit significant changes that contrast with their counterparts at larger scales, as quantum effects determine their new properties (VAZQUEZ-MUNOZ; LOPEZ-RIBOT, 2020).

Nanomaterials are widely used in different health-related applications, such as disinfectants, imaging tools, dressings, wearable devices, anticancer therapies, pharmaceuticals, drug delivery, vaccines, diagnostic techniques, and implants, among others (TOLEDO et al., 2020). Nanotechnologybased approaches should leverage the fight against COVID-19, as well as any future pandemics, in a 
variety of ways, including new vaccines, and drugs. Highly specific, rapid and sensitive tests to detect infection or to detect immunity (serological tests). Super thin filters for facial masks or blood filtration, new surfaces, or surface coatings that are resistant to viral adhesion and can inactivate the virus (WEISS et al., 2020).

In this context, the present study aimed to conduct a literature review on the advances in the design of personal protective equipment using nanotechnology to improve the antiviral properties and filtration capacity of the SARS-CoV-2.

\section{METHODOLOGY}

This study was characterized as an exploratory and integrative literature review type. This review retrieved and evaluated data available in databases on advances in personal protective equipment using nanotechnology to improve the antiviral properties and filtration capacity of the SARS-CoV-2.

\section{DATABASES AND STRING DEFINITION}

The research strategy used search strings built and adapted for three electronic databases: Web of Science, Scopus and PubMed. The string was based on predetermined groups of keywords related to nanotechnology, the SARS-CoV-2 virus and personal protective equipment, accordingly:

- Searching Component 1: nano*

- $\quad$ Searching Component 2: PPE OR mask OR coat OR glove OR clothes OR respirator OR filter OR fabric

- $\quad$ Searching Component 3: COVID-19 OR SARS-CoV-2

\section{RESEARCH STRATEGY, SELECTION PROCESS, AND STUDY SELECTION CRITERIA}

The advanced research in the databases was performed by pairs, considering research articles published until August 22, 2021, in which the authors conducted the preliminary selection and data extraction independently, in the identification stage and then proceeded to the stages of screening and inclusion, taking into account the inclusion and exclusion criteria, as described in Table 1. 
Table 1 - Inclusion and exclusion criteria in the review construction stages.

\begin{tabular}{|c|c|c|c|}
\hline Step & Inclusion criteria & Exclusion criteria & Based on \\
\hline Identification & Studies published in English & $\begin{array}{l}\text { Reviews, letters to the editor, notes, } \\
\text { duplicate articles }\end{array}$ & $\begin{array}{l}\text { Title, keywords and } \\
\text { abstracts }\end{array}$ \\
\hline Screening & $\begin{array}{l}\text { PPE studies with antiviral activities } \\
\text { At least one nanomaterial or nanoparticle } \\
\text { has been studied } \\
\text { Has a PPE or PPE material been developed }\end{array}$ & $\begin{array}{l}\text { No activity test was performed } \\
\text { No nanoscale materials strategy was } \\
\text { presented } \\
\text { No PPE or component development } \\
\text { studies have been portrayed }\end{array}$ & $\begin{array}{l}\text { Title, keywords and } \\
\text { abstracts }\end{array}$ \\
\hline Eligibility & - & Studies do not match study objectives & Reading full texts \\
\hline
\end{tabular}

Source: Authors' construction.

To extract data from the articles included in this study, the authors independently extracted and summarized the following information: product developed, type of nanomaterial used, potential application, functions and reference.

\section{RESULTS AND DISCUSSION}

The research in the databases resulted in the collection of 1990 articles, 642 in Web of Science, 495 in Scopus and 853 in PubMed. Of these, 34 adequately met the inclusion criteria and were selected for this data collection. Figure 1 shows the flowchart with the strategy for the selection of the articles included.

Figure 1 - Flowchart with the articles selection strategy.

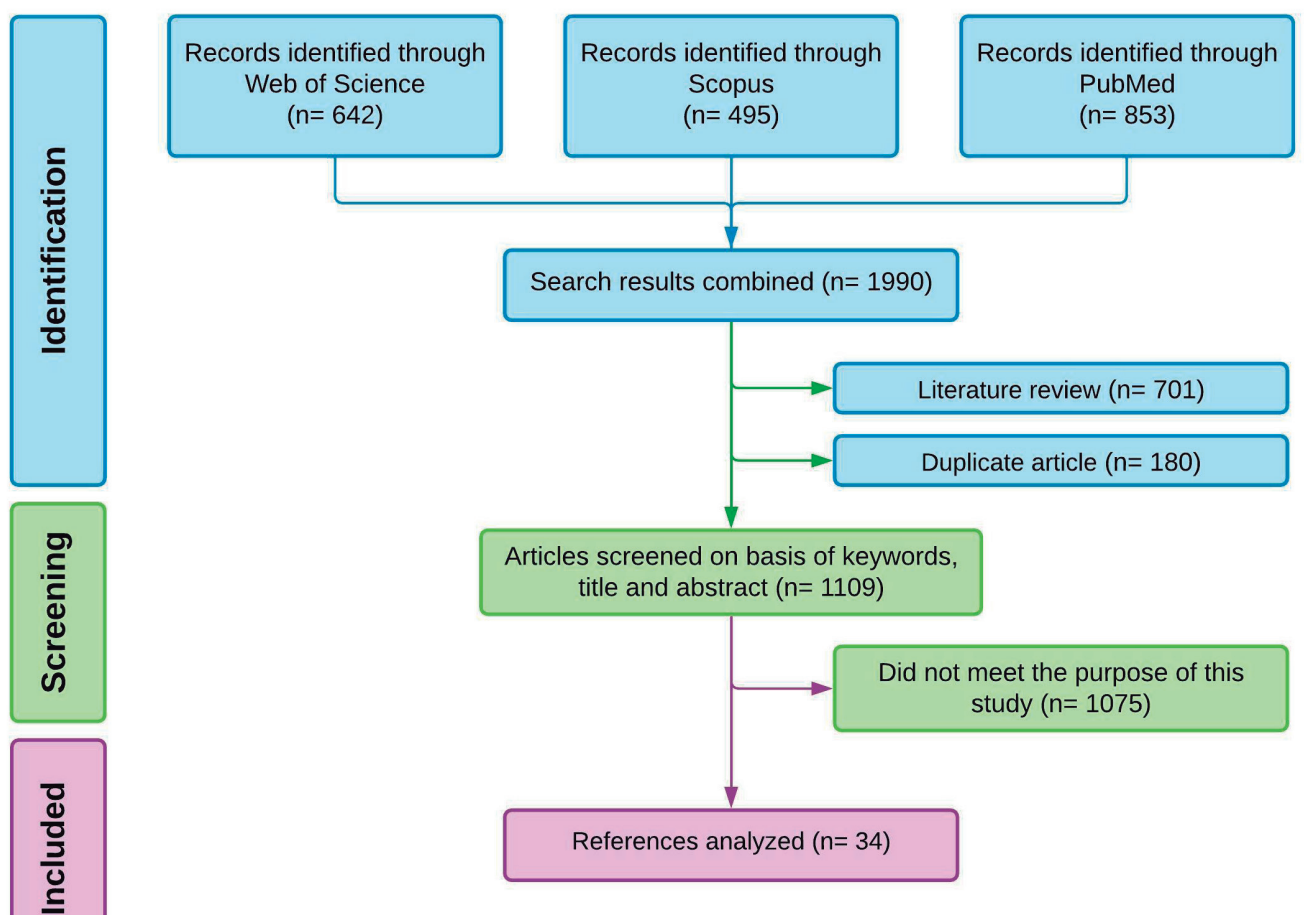

Source: Authors' construction. 
The studies that built up this review were published in 2020 (32\%) and until August 2021 (68 \%), with an increase in publications involving antiviral PPE with nanotechnology, in the second year of the COVID-19 pandemic. The Web of Science database sought $91 \%$ of the studies selected for this review, followed by Scopus (88 \%), and PubMed (82 \%). As no base showed $100 \%$ of the studies, it was essential to complement the bases for a more complete study. Of the 34 articles included in the study, $38 \%$ developed facial masks with antiviral or antimicrobial properties, $41 \%$ developed air filters for mask and respirator applications, and $21 \%$ developed antiviral surfaces for general PPE applications. These data make up Figure 2.

Figure 2 - Articles included by bases, year of publication, and developed products.

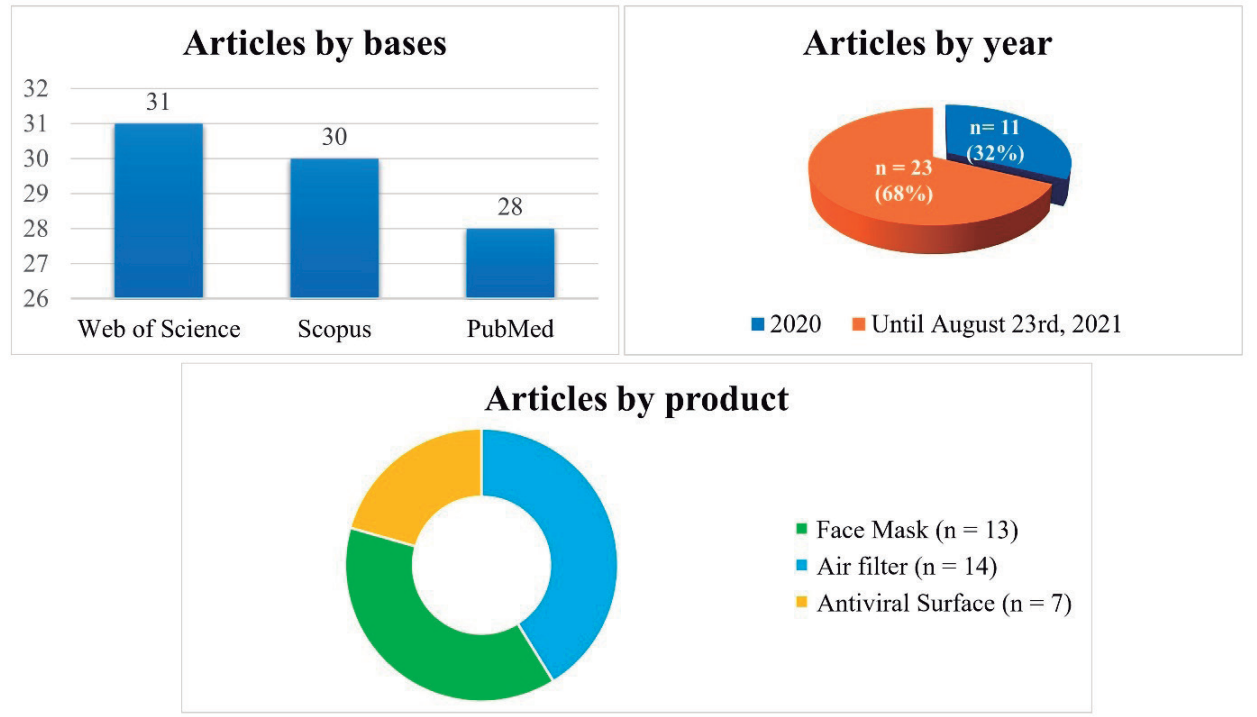

Source: Authors' construction.

Several nanostructures have been described and used in the development of PPE with antiviral and antimicrobial (antiviral + antibacterial) functions. They are copper nanoparticle and graphene oxide nanosheets (AHMED; AFIFI; USKOKOVIĆ, 2020), electrotrophied nanofibers and plasmonic gold nanoparticles (DE SIO et al., 2021), copper nanowires (KUMAR, A. et al., 2021), graphene nanosheet (LIN et al., 2021; PAL et al., 2021), C-dot (SINGH et al., 2021). They are also: thermoplastic polyurethane nanofibers (CHEN et al., 2021), titanium dioxide nanowires (HORVÁTH et al., 2020), polyacrylonitrile nanofiber containing zinc oxide nanoparticles (PARDO-FIGUEREZ et al., 2021), carbon nanotubes decorated with metals (AASI et al., 2020), zinc oxide nanorods and silver nanoparticles (KARAGOZ et al., 2021), Aloe vera nanofibers and polyvinyl alcohol (KHANZADA et al., 2020), among others. The main nanostructures used for the development of PPE with antiviral properties are shown in Figure 3.

In the development of nanostructured systems for application in PPE, important characteristics such as antiviral properties combined with mechanical or photoelectric properties, to eliminate the virus (XIE et al., 2020; KUMAR et al., 2021b), have been sought, in addition 
to characteristics such as biocompatibility (XIE et al., 2020), hydrophobicity (KUMAR et al., 2021b) and biodegradability (MÜLLER et al., 2021).

Figure 3 - Main types of nanostructures with antiviral properties used in the development of PPE.

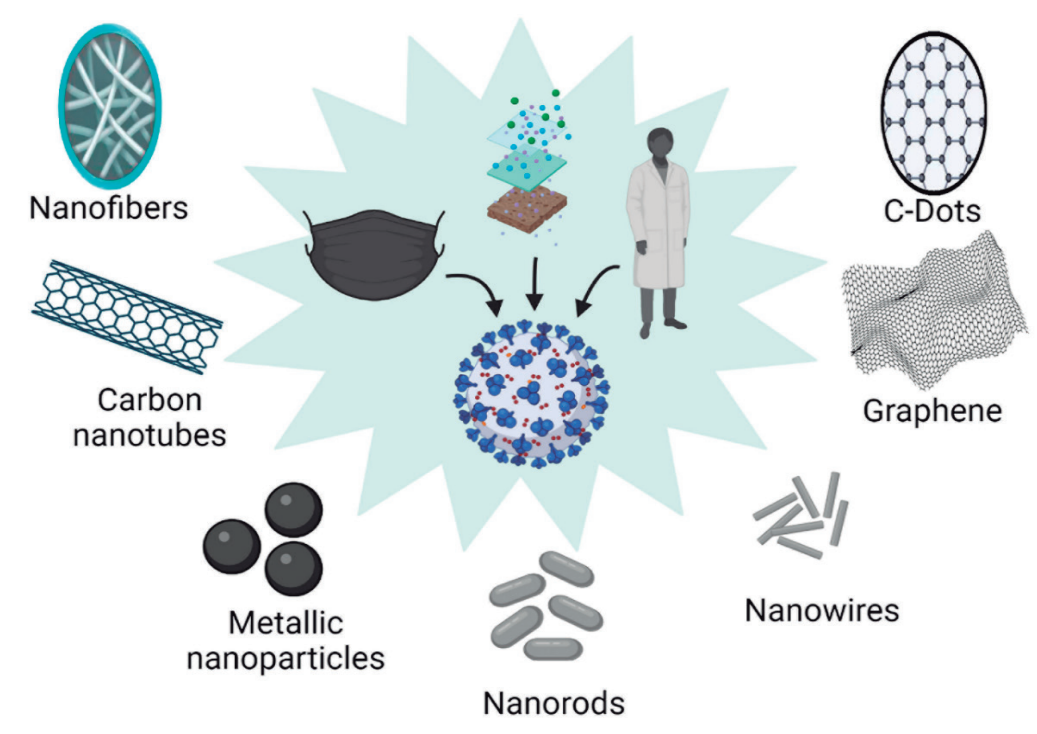

Source: Authors' construction.

Regarding the development of facial masks, 13 different studies were found using nanostructures with antiviral activity, which can be used to protect against SARS-CoV-2. The product developed, the type of nanostructure, and the functions of each study are shown in Table 2.

Table 2 - Nanostructures used in the development of antiviral facial masks.

\begin{tabular}{|c|c|c|c|}
\hline Developed Product & Type of Nanostructure & Function & Ref. \\
\hline $\begin{array}{l}\text { Recyclable reusable } \\
\text { facial mask }\end{array}$ & $\begin{array}{l}\mathrm{Cu} \text { oxide nanoparticle and } \\
\text { graphene oxide nanosheets }\end{array}$ & $\begin{array}{l}\text { Antimicrobial by virus and } \\
\text { bacteria deactivation }\end{array}$ & AHMED et al., 2020 \\
\hline $\begin{array}{l}\text { Recyclable reusable } \\
\text { facial mask }\end{array}$ & $\begin{array}{l}\text { PVA nanofibrous membrane and } \\
\text { licorice root extract }\end{array}$ & Antiviral by virus deactivation & CHOWDHURY et al., 2021 \\
\hline $\begin{array}{l}\text { Reusable } \\
\text { facial mask }\end{array}$ & $\begin{array}{l}\text { Electrotrophied nanofibers, } \\
\text { plasmonic gold nanoparticles }\end{array}$ & $\begin{array}{l}\text { Antimicrobial by light activation, } \\
\text { humidity control, and } \\
\text { effective filtration }\end{array}$ & DE SIO et al., 2021 \\
\hline $\begin{array}{l}\text { Self-powered } \\
\text { facial mask }\end{array}$ & $\begin{array}{l}\text { Simple triboelectric } \\
\text { nanogenerator (TENG) }\end{array}$ & $\begin{array}{l}\text { Virus deactivation by } \\
\text { mechanical energy capture }\end{array}$ & GHATAK et al., 2021 \\
\hline 3D mask with filter & Functionalized graphene & Antimicrobial & GOSWAMI et al., 2021 \\
\hline $\begin{array}{l}\text { Reusable } \\
\text { facial mask }\end{array}$ & $\mathrm{Cu}$ nanowires & $\begin{array}{l}\text { Antimicrobial by functionalization } \\
\text { with nanowires }\end{array}$ & KUMAR et al., 2021a \\
\hline $\begin{array}{l}\text { Self-cleaning and } \\
\text { reusable mask }\end{array}$ & $\begin{array}{l}\text { Shellac Nanocomposites and } \\
\mathrm{Cu} \text { Nanoparticles }\end{array}$ & $\begin{array}{l}\text { Surface hydrophobicity and } \\
\text { photothermal properties for } \\
\text { antimicrobial action }\end{array}$ & KUMAR, et al., 2021b \\
\hline Facial mask & $\begin{array}{l}\text { Amorphous calcium polyP } \\
\text { nanoparticles }\end{array}$ & $\begin{array}{l}\text { Antiviral, Biodegradable, } \\
\text { Moisture Resistant, Breathable }\end{array}$ & MÜLLER et al., 2021 \\
\hline $\begin{array}{l}\text { Reusable } \\
\text { facial mask }\end{array}$ & Graphene nanosheet & $\begin{array}{l}\text { Antimicrobial through photo } \\
\text { sterilization by sunlight }\end{array}$ & LIN et al., 2021 \\
\hline $\begin{array}{l}\text { Recyclable } \\
\text { facial mask }\end{array}$ & Graphene nanosheet & $\begin{array}{l}\text { Antimicrobial through photo } \\
\text { sterilization by sunlight }\end{array}$ & PAL et al., 2021 \\
\hline
\end{tabular}




\begin{tabular}{llll}
$\begin{array}{l}\text { Biodegradable } \\
\text { facial mask }\end{array}$ & $\begin{array}{l}\text { Nano-fibrous PLA functionalized } \\
\text { with Indian herbal extract }\end{array}$ & $\begin{array}{l}\text { Antimicrobial, high breathability, } \\
\text { splash resistance, and } \\
\text { filtration efficiency }\end{array}$ & PATIL et al., 2021 \\
$\begin{array}{l}\text { Mank with } \\
\text { membrane }\end{array}$ & C-dot & $\begin{array}{l}\text { Antimicrobial, self sterilized by } \\
\text { sunlight induction, hydrophobic }\end{array}$ & SINGH et al., 2021 \\
$\begin{array}{l}\text { Facial mask with } \\
\text { self-decontamination }\end{array}$ & $\begin{array}{l}\text { Graphene and } \\
\text { Silver Nanoparticles }\end{array}$ & $\begin{array}{l}\text { Antimicrobial with photothermal } \\
\text { decontamination and } \\
\text { super-hydrophobic }\end{array}$ & ZHONG et al., 2020 \\
\hline
\end{tabular}

Source: Authors' construction.

Ahmed et al. (2020) developed a protocol for a reusable, recyclable, and antimicrobial facial mask, with copper oxide nanoparticles (CuONP) and graphene oxide (GO) nanosheets that deactivate viruses, and bacteria. $\mathrm{CuO}$ nanoparticles have a narrow energy gap (ALAYANDE; OBAID; KIM, 2020). Because of this, they have been used to inhibit fungi, bacteria, and viruses (VARAPRASAD et al., 2020). GO exhibits excellent mechanical properties, including high tenacity, as well as high electrical conductivity and biocompatibility (XIE et al., 2020). In the study published by Chowdhury et al. (2021), the polyvinyl alcohol (PVA) nanofibrous membrane and licorice root extract were used in the production of a reusable, recyclable facial mask with antiviral properties due to licorice root, a herb traditionally used in the Asian region, which it has antiviral properties and the potential to weaken virus activity (CHIRUMBOLO, 2016).

De Sio et al. (2021) produced a reusable facial mask using electrotrophied nanofibers and plasmonic gold nanoparticles, with antimicrobial activity by light activation, and also achieved effective moisture control and filtration. The possibility of light-assisted photothermal disinfection is due to the photothermal sensitivity of plasmonic nanoparticles, such as gold (AMENDOLA et al., 2017). Owing to this nanotechnology-assisted disinfection and the mechanical strength of nanofibers, masks can be continuously sterilized and can be used several times (DE SIO et al., 2021). In the study by Ghatak et al. (2021), the authors describe a self-powered facial mask, in which a simple triboelectric nanogenerator (TENG) with an electrocution layer that works as filtration and deactivation of SARS-CoV-2, in which viral particles suffer a mild shock due to electric field produced between the electrocution layers by contact electrification, thus being deactivated.

In the study developed by Kumar et al. (2021a), Cu nanowires were used with antimicrobial function in reusable facial masks. Inorganic nanomaterials such as copper have attracted interest for their antimicrobial activity, as they release copper ions that are responsible for the generation of reactive oxygen species, which damage RNA and cause lipid peroxidation, destroying viruses and bacteria (SLAVIN et al., 2017). Kumar et al. (2021b) also used copper due to its antimicrobial property, where they applied a hybrid of shellac nanocomposites and $\mathrm{Cu}$ nanoparticles in a surgical mask, thus increasing surface hydrophobicity and repelling aqueous particles, and also conferred reusability and self-sterilization under solar lighting. 
Goswami et al. (GOSWAMI et al., 2021), Lin et al. (LIN et al., 2021) and Pal et al. (PAL et al., 2021) used graphene nanosheets in the development of reusable antimicrobial facial masks, with hydrophobic characteristics and photo sterilization in sunlight, due to the properties of graphene. The graphene layer used inhibits both airborne transmissions, preventing atomization and inhalation of virus-carrying aerosols, and direct communication, preventing the spread of viruses and droplets (CHUA et al., 2020). Zhong et al. (2020) also made use of graphene in the development of photothermal and super-hydrophobic respirators. In addition to graphene, they used silver nanoparticles (AgNP) that can provide additional protection through disinfection with silver ions. This synergism between graphene and AgNP provides the respirator with better protection when fighting the COVID-19 pandemic (ZHONG et al., 2020).

In the study published by Müller et al. (2021) amorphous calcium inorganic polyphosphate nanoparticles (Ca-polyP-NP) were used in the production of an anti-COVID-19 facial mask responsive to stimuli and virus inactivation. Polyphosphate is a biocompatible, biodegradable, and antiviral active physiological polymer, and with nanoparticles are used as a transporter of tretinoin (all-transretinoic acid) that blocks the function of the SARS-CoV-2 protein (MÜLLER et al., 2021). In the study by Patil et al. (2021) a biodegradable antimicrobial facial mask was developed from nanofibrous polylactic acid (PLA) functionalized with extract of Indian herbs (Azadirachta Indica and Eucalyptus Citriodora). The incorporation of an electrotrophied nano-fibrous layer in the mask improved the filtering ability and the addition of Indian herbs demonstrated effective performance in neutralizing viruses and bacteria. Singh et al. (2021) used nanoporous membranes comprising carbon dots (C-dots) and poly (vinylidene fluoride) (PVDF) in antimicrobial, hydrophobic, and self-sterilized masks by sunlight induction. The C-dots were used for their excellent photothermal properties, so the heat dissipated by the collection of sunlight by the C-dots can lead to the destruction of viral particles, without the need for external sterilization procedures.

Facial masks are considered the most effective means of preventing infections and dissemination of viral particles, such as the COVID-19 virus, but their production and disposal consume substantial resources, causing serious environmental damage, due to the increase in use by the world population. This review showed that studies have been concerned with developing reusable antimicrobial or antiviral masks to reduce environmental damage, combined with other functions such as biodegradability, self-feeding, self-decontamination, hydrophobicity, and increased filtration and breathability. For this purpose, nanostructures such as CuONP, graphene and GO, nanofibers, AuNP, CuNP, and AgNP were applied to deactivate SARS-CoV-2 through the virus protein denaturation, be that by capturing solar or mechanical energy.

According to the WHO (2020), the masks can be composed of several arrangements of fabrics, different sequences of layers, dividing the mask into three layers, the innermost being composed of hydrophilic fibers, while the intermediate and external layers need to have hydrophobic fibers. Thus, 
masks can be hierarchically designed according to porosity and hydrophobicity, where the outer layer has greater porosity and extreme water resistance than the innermost layer (RAWAL, 2020).

When researched on nanostructures used in the development of antiviral air filters and their potential uses, 14 different studies were found using nanostructures with antimicrobial and antiviral activity, which can be used to protect against SARS-CoV-2. The product developed, the type of nanostructure, and the functions of each study are shown in Table 3.

Table 3 - Nanostructures used in the development of antiviral air filters and their potential uses.

\begin{tabular}{|c|c|c|c|c|}
\hline Developed Product & Type of Nanostructure & Function & $\begin{array}{c}\text { Potential } \\
\text { application }\end{array}$ & Ref. \\
\hline $\begin{array}{l}\text { Biodegradable air } \\
\text { filter medium }\end{array}$ & $\begin{array}{l}\text { Cellulose acetate nanofibers and } \\
\text { cationic surfactant cetyl } \\
\text { pyridinium bromide }\end{array}$ & Antimicrobial & Facial masks & $\begin{array}{l}\text { ALMEIDA } \\
\text { et al., } 2020\end{array}$ \\
\hline $\begin{array}{l}\text { Nanofibrous } \\
\text { membrane }\end{array}$ & $\begin{array}{l}\text { PVA and TPU nanofiber } \\
\text { membranes with Ag nanoparticles }\end{array}$ & Antimicrobial & PEE & $\begin{array}{l}\text { ALSHABANAH } \\
\text { et al., } 2021\end{array}$ \\
\hline Filter & $\begin{array}{l}\text { Electrotrophied nanofibers of PVA } \\
\text { doped with AgNPs }\end{array}$ & Antimicrobial & Facial masks & BLOSI et al., 2021 \\
\hline Air filter & $\begin{array}{l}\text { Thermoplastic polyurethane } \\
\text { nanofibers }\end{array}$ & Antiviral & Facial masks & CHEN et al., 2021 \\
\hline Filter & Electrotrophied nanofibers & Antimicrobial & Facial masks & CHOI, S. et al., 2021a \\
\hline Air filter & Nanocapsule LAP-Cu${ }^{2+}$ & Antimicrobial & Facial masks & CHOI, D. et al., 2021b \\
\hline $\begin{array}{l}\text { Porous } \\
\text { membrane }\end{array}$ & $\begin{array}{l}\text { Nanoporous mold based on } \\
\text { silicon oxide }\end{array}$ & Antiviral & $\begin{array}{l}\text { Fixed on } \\
\text { N95 mask }\end{array}$ & EL-ATAB et al., 2020 \\
\hline Air filter & Titanium Dioxide Nanowires & Antiviral & Facial masks & $\begin{array}{l}\text { HORVÁTH } \\
\text { et al., } 2020\end{array}$ \\
\hline Air filter & Polyvinylidene Fluoride Nanofibers & Antiviral & $\begin{array}{l}\text { Respirators, } \\
\text { facial masks }\end{array}$ & (LEUNG; SUN, 2020a) \\
\hline Air filter & Polyvinylidene Fluoride Nanofibers & Antiviral & Facial masks & LEUNG; SUN, 2020b \\
\hline $\begin{array}{l}\text { Nanofibrous } \\
\text { membrane }\end{array}$ & $\begin{array}{l}\text { Nanofibrous membrane loaded } \\
\text { with active luminogen }\end{array}$ & Antimicrobial & $\begin{array}{c}\text { Reusable } \\
\text { bioprotective PPE }\end{array}$ & LI et al., 2021 \\
\hline Filters & $\begin{array}{l}\text { Polyacrylonitrile nanofiber } \\
\text { containing zinc oxide nanoparticles }\end{array}$ & Antimicrobial & Respirators & $\begin{array}{l}\text { PARDO-FIGUEREZ } \\
\text { et al., } 2021\end{array}$ \\
\hline Air filter & Electrotrophied PVDF Nanofibers & Antiviral & Facial masks & SHEN et al., 2021 \\
\hline $\begin{array}{l}\text { Nanofibrous } \\
\text { membrane }\end{array}$ & $\begin{array}{l}\text { Polystyrene nanofibers grafted by } \\
5,5 \text {-dimethylhydantoin and } \\
\text { trimethylamine }\end{array}$ & Antimicrobial & Facial masks & TIAN et al., 2021 \\
\hline
\end{tabular}

Source: Authors' construction.

Almeida et al. (2020) developed in their study biodegradable nanofibers of cellulose acetate and cationic surfactant cetyl pyridinium bromide (CA/CPB), produced by electrospinning technique to efficiently retain the airborne nanoparticles. Thus, the authors developed electrotrophied nanofibers with an average particle diameter of $239 \mathrm{~nm}$, ranging from 113 to $398 \mathrm{~nm}$. From the results obtained in this research, it was possible to conclude that CA / CEC can be applied to capture nanometric particles, smaller than $300 \mathrm{~nm}$, with a high filtration rate, including the new 2019 coronavirus. This research provided information for future air filter projects internal and filter media for facial masks with renewable characteristics, biodegradable non-toxic, and antibacterial potential. 
Alshabanah et al. (2021) nanofibrous hybrids are manufactured, characterized, and assessed as active antiviral and antibacterial membranes. In more detail, both polyvinyl alcohol (PVA developed an antiviral/antibacterial membrane from synthetic and biodegradable electrotrophied nanofibers that can be used as a promising functional layer in personal protective equipment (PPE), such as lab coats and other hospital equipment. The developed nanofibers, moplastic polyurethane (TPU), and polyvinyl alcohol (PVA) loaded with silver nanoparticles (AgNPs) were characterized and investigated for their potential antiviral and antibacterial activities as well. The results showed that TPU-Ag was more effective than PVA-Ag as an antiviral HIV-1 nanohybrid, as well as in deactivating SARS-CoV-2 peak proteins. The TPU-Ag and PVA-Ag nanofibrous membranes demonstrated superior antimicrobial performance, increasing the Ag concentration from 2 to $4 \%$ by weight. Furthermore, the developed membranes showed acceptable physical and mechanical properties, along with antiviral and antibacterial activities, which may allow them to be used as a promising functional layer in Personal Protective Equipment (PPE).

Blosi et al. (2021)we designed a new class of high performant filter media suitable to advance the facemask technology and provide new efficient widespread solutions against virus propagation. By means of the electrospinning technology we developed filter media based on polyvinyl alcohol (PVA developed filter media based on polyvinyl alcohol (PVA) nanofibers doped with silver nanoparticles (AgNPs) combining requirements for high performance, they being high air filtration efficiency to capture nano-sized particles, low airflow resistance essential for ensuring breathability and antimicrobial activity to inactivate aerosolized microorganisms. They achieved filter media characterized by exceptional performance requirements for masking purposes, such as high air filtration efficiency and low-pressure drop expressed by QF values comparable to or better than commercial filter media. In addition, they evaluated a total bacterial depletion associated with a filtration efficiency for nanoaerosolized particles of $97.7 \%$ greater than that required by the EN149 standard and a pressure drop in line with the FFP1 and FFP2 masks, even at the highest filtration speed.

Chen et al. (2021) developed thermoplastic polyurethane nanofiber membrane-based air filters for efficient removal of $\mathrm{PM}_{0.1}$ ultra-fine particulate matter. Cast or electrospun nanofibers are considered ideal for resistance to aerosol particles containing viruses, eliminating air pollution by particulate matter, and protecting public health. The air filter developed by the authors demonstrated the attributes of high $\mathrm{PM}_{0.1}$ removal efficiency of up to $97.08 \%$, a pressure drop of $\sim 8 \mathrm{~Pa}$, the quality factor of $0.061 \mathrm{~Pa}^{-1}$, and good optical transparency with only $6 \mathrm{~g} . \mathrm{m}^{-2}$ basis weight. This is innovative compared to existing air filters based on micro/nanofiber membrane for ultra-fine particle filtration and can be used in face masks, filtering aerosol particles containing viruses, including the COVID-19 virus.

Choi et al. (2021) developed a biodegradable, moisture-resistant, highly breathable, high-performance fibrous mask filter based on poly(butylene succinate) (PBS) and chitosan nanowhiskers (CsW). The filter developed was as efficient as the commercial N95 filter and removes $98.3 \%$ of $2.5 \mu \mathrm{m}$ of particulate matter (PM). The nanofiber sieve physically fine PM and the microfiber provides a 
low-pressure differential of $59 \mathrm{~Pa}$, which is comfortable to breathe and has not significantly lost filtering when exposed to moisture, unlike the N95 filter, which loses performance. Therefore, the new filter is multifunctional because chitosan's permanent dipoles adsorb ultra-fine PM (e.g. nitrogen and sulfur oxides). Furthermore, unlike commercial disposable facial masks, the developed filter is sustainable; it fully biodegrades in 1 month in composted soil.

Choi et al. (2021)the indoor environment provides a unique exposure situation to induce infection through airborne transmission like SARS-CoV-2. To prevent the infection from spreading, personal protective equipment or indoor air purification is necessary. However, it has been discovered that the conventional filter can become contaminated by pathogen-containing aerosols, meaning that advanced filtering and self-sterilization systems are required. Here, we fabricate a multilayered nanocoating around the fabric using laponite (LAP fabricated a multilayer nano-coating around the fabric using Laponite (LAP) with $\mathrm{Cu}^{2+}$ ions (LAP- $\mathrm{Cu}^{2+}$ nano-coating) two contradictory functions in a system: entrapment of protein pathogens and antibacterial effect. Due to the strong LAP-protein interaction, albumin and the spike protein (protein $\mathrm{S}$ ) are trapped in the tissue when the proteins are sprayed using a nebulizer. The protein blocking performance of the nano-coated fabric is 9.55 times that of normal fabric. These trapping capabilities are maintained after repeated rinsing and adsorption cycles, showing reproducibility for air filtration. Even though protein binding has occurred, LAP-Cu ${ }^{2+}$ tissue indicates an antibacterial effect. The LAP- $\mathrm{Cu}^{2+}$ tissue has a transmission rate of air and water equivalent to that of the naked tissue, with stability in a physiological environment. Therefore, due to its excellent "spear and shield" functions, the proposed LAP- $\mathrm{Cu}^{2+}$ fabric has great potential for use in filters and masks during the viral pandemic.

In the study developed by El-Atab et al. (2020), they performed the synthesis of a flexible nanoporous mold for the design and development of reusable hydrophobic anti-COVID-19 facial masks. The development of a nanoporous membrane attachable to a reusable N95 mask and replaceable after each use has been demonstrated. The porous membrane is based on a naturally hydrophobic polymer, so the droplets that come into contact with the mask will roll and slide over the mask due to the large angle of inclination of the membrane when used in the full facial mask. The results showed nanopores with sizes below $5 \mathrm{~nm}$ and theoretical calculations to assess the breathability of the obtained membrane showed airflow rates above $85 \mathrm{~L} \mathrm{~min}^{-1}$. As such, the flexible membrane can be used in a reusable N95 mask to increase its filtering efficiency against particles below $300 \mathrm{~nm}$, including the COVID-19 virus.

Horvath et al. (2020) developed an air filter based on $\mathrm{TiO}_{2}$ photocatalytic nanowires $\left(\mathrm{TiO}_{2}\right.$ NWs) for personal protection equipment, as well as for a new generation of air conditioners and air purifiers. The immediate importance of such a filter is represented by the urgency of the Covid-19 crisis, which quickly spread to a pandemic. As a result, the authors obtained $\mathrm{TiO}_{2} \mathrm{NWs}$ that can be processed into films by scraping, screen printing, filtering, dip-coating, and spin-coating with a thickness of fewer than $2 \mu \mathrm{m}$. 
Leung and Sun (2020a) developed electrostatically charged multilayer/multimodule nanofiber (PVDF) filters for filtering new simulated airborne coronaviruses (COVID-19) using environmental nanoaerosols. The results demonstrate that electrostatically charged multilayer/multimodule (PVDF) nanofiber filters are potent candidates for facial masks, which can be used to protect against SARS-CoV-2. Another study by Leung and Sun (2020b) demonstrated the development of an electrostatically charged nanofiber filter to filter out new airborne coronaviruses (COVID-19) and nanoaerosols. With the multilayer/multimodule approach using small diameter nanofibers with small basis weight in modules, or large diameter nanofibers with large basis weight in modules, high-performance loaded nanofiber filters have been developed that achieve capture of more than 90\% COVID-19 airborne simulated by $100 \mathrm{~nm}$ sodium chloride aerosols. Thus, the filters developed are excellent in capturing viruses, especially SARS-CoV-2, which has a size range of 60-140 $\mathrm{nm}$ with an average size of $100 \mathrm{~nm}$.

Li et al. (2021)the inappropriate disposal and sterilization of PPE may result in a high risk of cross-contamination. Therefore, the exploration of antimicrobial materials possessing both microbe interception and self-decontamination effects to develop reusable and easy-to-sterilize PPE is of great importance. Herein, an aggregation-induced emission (AIE used the electrospinning technique to develop a nanofibrous membrane loaded with aggregation-induced emission (AIE) active luminogenic (TTVB @ NM) sharing photodynamic/photothermal antipathogen functions triggered by sunlight. After irradiation with sunlight, TTVB @ NM can generate massive ROS, which plays a dominant role for the microbicide effect, and exhibits a moderate photothermal conversion performance that plays an adjuvant role for the inhibition of microbes, synergistically providing its effective application for sunlight-triggered inactivation of various microbes, including bacteria, fungi, and viruses. A series of antimicrobial evaluations revealed that TTVB @ NM can effectively inactivate pathogenic aerosols containing bacteria (inhibition rate: $>99 \%)$, fungi $(\sim 88 \%)$, and viruses ( $>99 \%$ ) in just 10 minutes of solar irradiation.

Pardo-Figuerez et al. (2021) developed antimicrobial filters based on polyacrylonitrile nanofibers (PAN) for high filtration efficiency respirators. The fibers were deposited onto polypropylene non-woven material in rolled form (SPP). The results suggested that a symmetric structure based on SPP / PAN / PAN / SPP was the ideal structure, as it has maintained the filtration efficiency of the FFP2 mask type, as well as reduced respiratory resistance, especially at high airflow rates such as the FFP2. Furthermore, the incorporation of zinc oxide $(\mathrm{ZnO})$ nanoparticles in electrospinned nanofibers in the form of nanocomposites maintained the high filtration characteristics of the unfilled filter, although exhibiting a strong bactericidal capacity, even after short contact times. This study expresses the possibility of producing a high filtration efficiency filter medium with antimicrobial properties.

Shen et al. (2021) used coronavirus aerosols to challenge air filters and facial masks and to assess their efficiency. They have developed electrotrophied nanofibrous air filters with a reduced 
pore size that can effectively capture viral aerosols. Due to the ultra-fine $(\sim 300 \mathrm{~nm})$ nanofibers, the electrospinned air filters had a much smaller pore size compared to the surgical mask and tissue masks (a few micrometers versus tens to hundreds of micrometers). Electrotrophied air filters have shown excellent performance, capturing up to $99.9 \%$ of coronavirus aerosols, outperforming many commercial facial masks.

To complete the studies found on nanostructures used in the development of antiviral air filters and their potential uses, Tian et al. (2021) synthesized antibacterial and antiviral N-halamine nanofiber membranes with a nanonet structure for bioprotective applications. They designed membranes that exhibited integrated properties of high fine particle interception (96.7\%) and low-pressure drop (95.4 Pa). Furthermore, the nanofiber membranes exhibited superior bactericidal (>99.99\%) and virucidal ( $>99.99 \%$ ) efficiency in a short time ( $2 \mathrm{~min})$, which allows the nanofibers to be used as a filtration material, providing interception bacterial (99.77\%) and death by contact against pathogens.

Conventional filters, used in masks, are disposable and are not biodegradable and recyclable, generating a high amount of waste in the environment, as seen in masks without nanotechnology, in addition to losing their effectiveness in humid conditions. Another problem with conventional filters is their use in valves or one-way mask openings, where the virus spreads through released respiratory droplets. To overcome these adversities, studies have resorted to nanotechnology, such as the use of electrospinned nanofibers, to which Electrospinning is an emerging technology to synthesize non-woven nanofiber membranes that are ideal for air filtration (AGARWAL, WENDORFF e GREINER, 2008).

In addition to the use of $\mathrm{SiO}, \mathrm{TiO}_{2}, \mathrm{ZnO}, \mathrm{AgNPs}$, and $\mathrm{LAP}-\mathrm{Cu}^{2+}$ nanocapsules, to control the transmission of SARS-CoV-2, and thus use these filters in different types of PPE. These nanostructures can add characteristics of biodegradability, nontoxicity, hydrophobicity, and reuse of filters, which, together with the antiviral properties of nanomaterials, become good alternatives for controlling the proliferation of SARS-CoV-2.

Further to the articles described above, data described in Table 4 demonstrate that we found 7 different studies on nanostructures used in the development of antiviral surfaces and their potential uses in protection against SARS-CoV-2.

Table 4 - Nanostructures used in the development of antiviral surfaces and their potential uses.

\begin{tabular}{|c|c|c|c|c|}
\hline Developed Product & Type of Nanostructure & Function & $\begin{array}{c}\text { Potential } \\
\text { application }\end{array}$ & Ref. \\
\hline Antiviral surface & $\begin{array}{l}\text { Carbon nanotubes decorated } \\
\text { with metals }(\mathrm{Pt} \text { and } \mathrm{Cu})\end{array}$ & Antiviral & PPE & AASI et al., 2020 \\
\hline $\begin{array}{l}\text { Nanoceutical } \\
\text { cotton fabric }\end{array}$ & $\mathrm{ZnO}$ nanoflowers & Antimicrobial & $\begin{array}{l}\text { Facial mask } \\
\text { and Clothes }\end{array}$ & ADHIKARI et al., 2021 \\
\hline $\begin{array}{l}\text { Multifunctional } \\
\text { nanofibers }\end{array}$ & $\begin{array}{l}\mathrm{ZnO} \text { Nanofibers and } \\
\text { Ag Nanoparticles }\end{array}$ & Antimicrobial & $\begin{array}{l}\text { Protective } \\
\text { clothing }\end{array}$ & KARAGOZ et al., 2021 \\
\hline $\begin{array}{l}\text { Antimicrobial } \\
\text { nanofibers }\end{array}$ & Aloe Vera and PVA Nanofibers & Antimicrobial & $\begin{array}{l}\text { Protective } \\
\text { clothing }\end{array}$ & KHANZADA et al., 2020 \\
\hline
\end{tabular}




\begin{tabular}{llccc}
$\begin{array}{l}\text { Superhydrophobic } \\
\text { surface }\end{array}$ & Cu nanoparticles & Antimicrobial & Fomites & $\begin{array}{c}\text { MEGUID; } \\
\text { ELZAABALAWY, 2020 }\end{array}$ \\
$\begin{array}{l}\text { Antimicrobial } \\
\text { coating }\end{array}$ & $\mathrm{Ag}, \mathrm{CuO}$, and ZnO nanoparticles & Antimicrobial & Fomites & MERKL et al., 2021 \\
$\begin{array}{l}\text { Biocidal } \\
\text { nanofibers }\end{array}$ & Nanofibers & Antimicrobial & $\begin{array}{c}\text { Clothes and } \\
\text { Facial Masks }\end{array}$ & WU et al., 2021 \\
\hline
\end{tabular}

Source: Authors' construction.

Surfaces capable of detecting, inactivating, and removing viruses from the air or fomites are vital to prevent viral transmission, especially in pandemics such as the ones caused by SARS-CoV-2. Reactive oxygen species (ROS) promoting molecules such as peroxides are harmful to many viruses, including coronaviruses. In the article published by Aasi et al. (2020), metal-decorated single-wall carbon nanotubes (SWCNTs) were evaluated for the adsorption of hydrogen peroxide $\left(\mathrm{H}_{2} \mathrm{O}_{2}\right)$ for potential use in the design of viral inactivation surfaces such as filter nanomaterials, PPE, and virus detection devices. SWNCT has shown potential as a largely unexplored substrate for capturing, inactivating, and controlling viral infectious diseases. Adhikari et al. (2021) used zinc oxide nanoflowers ( $\mathrm{ZnO} N F s$ ) in the development of a nanoceutical cotton fabric with antimicrobial activity. This fabric was developed for use in clothing and face masks to increase breathing comfort and deactivate SARSCoV-2 viruses through Spike protein denaturation.

Karagoz et al. (2021), investigated the potential of using multifunctional poly(methyl methacrylate) nanofibers decorated with $\mathrm{ZnO}$ nanorods and $\mathrm{Ag}$ nanoparticles in protective mats. The new material showed high performance, featuring four functionalities (I) antibacterial agent, (II) antiviral agent to inhibit corona and influenza viruses, (III) photocatalyst for degradation of organic pollutants, allowing a self-cleaning protective mat, and (IV) Raman scattering substrate, with an improved reusable surface for quantitative analysis of trace pollutants on nanofiber. The multifunctional material also showed high potential for use in the application of protective clothing. Khanzada et al. (2020) also manufactured nanofibers in their studies but using Aloe Vera and Polyvinyl Alcohol (AV/PVA). The antimicrobial activity of the AV/PVA electrotrophied nanofibers was excellent and therefore these fibers are more suitable for the preparation of protective clothing (lab coats, face masks, etc.) used against COVID-19.

Literature indicates that copper $(\mathrm{Cu})$ may play a crucial role in further eliminating the risk of the virus. Copper fomites have been found to have antiviral properties against Influenza A virus particles and are also the fastest to eliminate SARS-CoV-2 virus particles when compared to other materials. Therefore, Meguid and Alzaabalawy (2020) studied the potential of implementing superhydrophobic surfaces incorporated with $\mathrm{Cu}$ nanoparticles to reduce virus transmission. They were able to manufacture nanocomposites with antibacterial and antiviral activities, which can repel contaminated particles, providing improved protection on surfaces used in public and healthcare facilities. These nanocomposites can be applied to coating surfaces or synthesized in masse into super-hydrophobic monoliths. 
Coatings of $\mathrm{Ag}, \mathrm{CuO}$, and $\mathrm{ZnO}$ on flat solid substrates (glass) and also on porous filter media (fiberglass filters and FFP3 filters) were produced by Merkl et al. (2021), to study its antiviral activity against SARS-CoV-2. Among the three nanomaterials studied, nanosilver exhibited the highest antiviral activity against SARS-CoV-2. After 5 minutes, the viral load was reduced by $75 \%$ and, after 120 minutes, by $98 \%$. During the incubation of the nano-coatings with the drop containing the virus, the virus particles could be inactivated both by their direct interaction with the surface and by their interaction with the released ions $\left(\mathrm{Ag}^{+}, \mathrm{Cu}^{2+}\right.$ e $\left.\mathrm{Zn}^{2+}\right)$. The results of this research provide the necessary guidance for the healthcare industry to use antiviral coatings on solid surfaces against fomite transmission, leading to super scattering events, as well as to mitigate aerosol transmission by using air filtration units to nanosilver basis for the current COVID-19 pandemic and any future pandemics caused by similar pathogens.

$\mathrm{Wu}$ et al. (2021) presented green nanofibers with effective antibacterial and antiviral activities that can provide sustainable bioprotection through the continuous production of reactive oxygen species (ROS). The design's superiority is that nanofibers can absorb and store visible light energy and maintain activity in a light or dark environment. Furthermore, nanofibers can release ROS uninterruptedly in the absence of an external hydrogen donor, acting as a biocide in all weather conditions. The PPE modified with nanofibers exhibit stable ROS production, excellent long-term durability, and high bactericidal (>99.9\%) and virucidal (>99.999\%) activity.

With the world pandemic decree, the demand for PPE increased, but most tissues used in the manufacture of this PPE do not have or are deficient in biocidal properties. Because of this, several studies have proposed the addition of nanostructures to surfaces, making them antiviral or even antimicrobial, examples of nanostructures found in this integrative review are: carbon nanotubes decorated with metals, $\mathrm{ZnO}$ and $\mathrm{AgNP}$ nanofibers, Aloe Vera nanofibers, and nanoparticles of $\mathrm{Cu}, \mathrm{Ag}$, $\mathrm{CuO}$ and $\mathrm{ZnO}$. With the use of nanotechnology, the surfaces, in addition to blocking the virus, manage to deactivate it and can be used in facial masks, protective clothing, fomites, and PPE in general.

\section{CONCLUSION}

Nanomaterials have a wide spectrum of interesting properties that make them useful as potential nanomedicine and prophylactic tools against COVID-19. In this integrative literature review, the articles analyzed to show that different nanostructures have been used to develop facial masks, air filters, and surfaces with antiviral properties, to deactivate the SARS-CoV-2 virus through these PPEs. Understanding the interface between the studied nanomaterials and coronaviruses is essential for designing target antivirals for COVID-19 infection.

Through this review, it can be concluded that the main nanostructures used in the development of face masks, filters, and antiviral surfaces are nanofibers, carbon nanotubes, metallic nanoparticles, 
nanorods, nanowires, graphene, and C-dots, e when compared to traditional PPE, PPE manufactured using nanoparticles exhibited advantages as prophylactic tools against COVID-19: i) NPs increase surface hydrophobicity by repelling aqueous particles; ii) the NPs provide reusability and self-sterilization under sunlight; iii) NPs have antimicrobial and viricidal activity with the ability to cause death or viral inactivation of pathogens by contact. Although promising results have been found in the different articles, there are still some challenges (for example, how to optimize the production of these PPE and nanoparticles, what are the possible effects of disposing of these PPE containing nanoparticles in the environment). Therefore, future studies on PPE containing nanoparticles should pay more attention to these issues. Overall, these new PPE are expected to make major contributions to decreasing the spread and spread of COVID-19 and other diseases transmitted by viruses and bacteria.

\section{ACKNOWLEDGMENTS}

This work was carried out with the support of the Coordenação de Aperfeiçoamento de Pessoal de Nível Superior - Brazil (CAPES) - Financing Code 001.

\section{REFERENCES}

AASI, A. et al. Pt-, rh-, ru-, and cu-single-wall carbon nanotubes are exceptional candidates for design of anti-viral surfaces: A theoretical study. International Journal of Molecular Sciences, v. 21, n. 15, p. 1-23, 2020. Available in: https://doi.org/10.3390/ijms21155211

ADHIKARI, A. et al. Nanoceutical Fabric Prevents COVID-19 Spread through Expelled Respiratory Droplets: A Combined Computational, Spectroscopic, and Antimicrobial Study. ACS Applied Bio Materials, v. 4, n. 7, p. 5471-5484, 2021. Available in: https://doi.org/10.1021/acsabm.1c00238

AGARWAL, S.; WENDORFF, J.H.; GREINER, A.. Use of eletrospinning technique for biomedical applications. Polymer, v. 49, n. 26, p. 5603-5621, 2008. Available in: https://doi.org/10.1016/ j.polymer.2008.09.014

AHMED, M.K. et al. Protecting healthcare workers during COVID-19 pandemic with nanotechnology: A protocol for a new device from Egypt. Journal of Infection and Public Health, v. 13, n. 9, p. 1243-1246, 2020. Available in: https://doi.org/10.1016/j.jiph.2020.07.015 
ALAYANDE, A.B.; OBAID, M.; KIM, I.S. Antimicrobial mechanism of reduced graphene oxide-copper oxide (rGO-CuO) nanocomposite films: The case of Pseudomonas aeruginosa PAO1. Materials Science and Engineering C, v. 109, n. October 2019, p. 110596, 2020. Available in: https://doi.org/ 10.1016/j.msec.2019.110596

ALMEIDA, D.S. et al. Biodegradable CA/CPB electrospun nanofibers for efficient retention of airborne nanoparticles. Process Safety and Environmental Protection, v. 144, p. 177-185, 2020. Available in: https://doi.org/10.1016/j.psep.2020.07.024

ALSHABANAH, L.A. et al. Hybrid nanofibrous membranes as a promising functional layer for personal protection equipment: Manufacturing and antiviral/antibacterial assessments. Polymers, v. 13, n. 11, 2021. Available in: https://doi.org/10.3390/polym13111776

AMENDOLA, V. et al. Surface plasmon resonance in gold nanoparticles: a review. Journal of Physics: Condensed Matter, v. 29, n. 20, p. 203002, 2017. Available in: https://doi.org/10.1088/1361648X/aa60f3

BLOSI, M. et al. Polyvinyl alcohol/silver electrospun nanofibers: Biocidal filter media capturing virus-size particles. Journal of Applied Polymer Science, p. 1-10, 2021. Available in: https://doi.org/ 10.1002/app.51380

CARVALHO, A.P.A.; CONTE-JUNIOR, C.A. Recent Advances on Nanomaterials to COVID-19 Management: A Systematic Review on Antiviral/Virucidal Agents and Mechanisms of SARS-CoV-2 Inhibition/Inactivation. Global Challenges, v. 5, n. 5, p. 2000115, 2021. Available in: https://doi.org/ $10.1002 / \mathrm{gch} 2.202000115$

CHEN, R. et al. Thermoplastic Polyurethane Nanofiber Membrane Based Air Filters for Efficient Removal of Ultrafine Particulate Matter PM 0.1. ACS Applied Nano Materials, v. 4, n. 1, p. 182-189, 2021. Available in: https://doi.org/10.1021/acsanm.0c02484

CHIRUMBOLO, S. The antiviral and antimicrobial activities of licorice, a widely-used Chinese herb. Frontiers in Microbiology, v. 7, 2016. Available in: https://doi.org/10.3389/fmicb.2016.00531

CHOI, D. et al. Co-existing "spear-and-shield" air filter: Anchoring proteinaceous pathogen and self-sterilized nanocoating for combating viral pandemic. Chemical Engineering Journal, v. 426, p. 130763, 2021. Available in: https://doi.org/10.1016/j.cej.2021.130763 
CHOI, S. et al. Biodegradable, Efficient, and Breathable Multi-Use Face Mask Filter. Advanced Science, v. 8, n. 6, p. 1-8, 2021. Available in: https://doi.org/10.1002/advs.202003155

CHOWDHURY, M.A. et al. Prospect of biobased antiviral face mask to limit the coronavirus outbreak. Environmental Research, v. 192, p. 110294, 2021. Available in: https:/doi.org/10.1016/ j.envres.2020.110294

CHUA, M.H. et al. Face Masks in the New COVID-19 Normal: Materials, Testing, and Perspectives. Research, v. 2020, p. 1-40, 2020. Available in: https://doi.org/10.34133/2020/7286735

DE SIO, L. et al. Personalized Reusable Face Masks with Smart Nano-Assisted Destruction of Pathogens for COVID-19: A Visionary Road. Chemistry - A European Journal, v. 27, n. 20, p. 6112-6130, 2021. Available in: https://doi.org/10.1002/chem.202004875

EL-ATAB, N. et al. Flexible Nanoporous Template for the Design and Development of Reusable Anti-COVID-19 Hydrophobic Face Masks. ACS Nano, v. 14, n. 6, p. 7659-7665, 2020. Available in: https://doi.org/10.1021/acsnano.0c03976

GHATAK, B. et al. Photocatalytic Nanowires-Based Air Filter: Towards Reusable Protective Masks. Advanced Functional Materials, v. 13, n. June 2020, p. 1-8, 2021. Available in: https://doi.org/ 10.1021/acsami.0c15606

GOSWAMI, M. et al. Facile development of graphene-based air filters mounted on a 3D printed mask for COVID-19. Journal of Science: Advanced Materials and Devices, v. 6, n. 3, p. 407-414, 2021. Available in: https://doi.org/10.1016/j.jsamd.2021.05.003

HORVÁTH, E. et al. Photocatalytic Nanowires-Based Air Filter: Towards Reusable Protective Masks. Advanced Functional Materials, v. 30, n. 40, p. 1-8, 2020. Available in: https://doi.org/10.1002/ adfm.202004615

KARAGOZ, S. et al. Antibacterial, antiviral, and self-cleaning mats with sensing capabilities based on electrospun nanofibers decorated with $\mathrm{ZnO}$ nanorods and $\mathrm{Ag}$ nanoparticles for protective clothing applications. ACS Applied Materials and Interfaces, v. 13, n. 4, p. 5678-5690, 2021. Available in: https://doi.org/10.1021/acsami.0c15606 
KHAN, M. et al. COVID-19: A Global Challenge with Old History, Epidemiology and Progress So Far. Molecules, v. 26, n. 1, p. 39, 2020. Available in: https://doi.org/10.3390/molecules26010039

KHANZADA, H. et al. Fabrication of Promising Antimicrobial Aloe Vera/PVA Electrospun Nanofibers for Protective Clothing. Materials, v. 13, n. 17, p. 3884, 2020. Available in: https://doi.org/10.3390/ ma13173884

KUMAR, A. et al. Copper@ZIF-8 Core-Shell Nanowires for Reusable Antimicrobial Face Masks. Advanced Functional Materials, v. 31, n. 10, p. 2008054, 2021a.Available in: https://doi.org/10.1002/ adfm.202008054

KUMAR, S. et al. Photoactive Antiviral Face Mask with Self-Sterilization and Reusability. Nano Letters, v. 21, n. 1, p. 337-343, 2021b. Available in: https://doi.org/10.1021/acs.nanolett.0c03725

LEUNG, W.W.F.; SUN, Q. Charged PVDF multilayer nanofiber filter in filtering simulated airborne novel coronavirus (COVID-19) using ambient nano-aerosols. Separation and Purification Technology, v. 245, 2020a. Available in: https://doi.org/10.1016/j.seppur.2020.116887

LEUNG, W.W.F.; SUN, Q. Electrostatic charged nanofiber filter for filtering airborne novel coronavirus (COVID-19) and nano-aerosols. Separation and Purification Technology, v. 250, p. 116886, 2020 b. Available in: https://doi.org/10.1016/j.seppur.2020.116886

LI, M. et al. AIEgen-loaded nanofibrous membrane as photodynamic/photothermal antimicrobial surface for sunlight-triggered bioprotection. Biomaterials, v. 276, p. 121007, 2021. Available in: https://doi.org/10.1016/j.biomaterials.2021.121007

LIN, Z. et al. Superhydrophobic, photo-sterilize, and reusable mask based on graphene nanosheet-embedded carbon (GNEC) film. Nano Research, v. 14, n. 4, p. 1110-1115, 2021. Available in: https://doi.org/10.1007/s12274-020-3158-1

MEGUID, S.A.; ELZAABALAWY, A. Potential of combating transmission of COVID-19 using novel self-cleaning superhydrophobic surfaces: part I-protection strategies against fomites. International Journal of Mechanics and Materials in Design, v. 16, n. 3, p. 423-431, 2020. Available in: https://doi.org/10.1007/s10999-020-09513-x 
MERKL, P. et al. Antiviral activity of silver, copper oxide and zinc oxide nanoparticle coatings against sars-cov-2. Nanomaterials, v. 11, n. 5, 2021. Available in: https://doi.org/10.3390/nano11051312

MÜLLER, W.E.G. et al. Triple-target stimuli-responsive anti-COVID-19 face mask with physiological virus-inactivating agents. Biomaterials Science, 2021. Available in: https://doi.org/10.1039/ $\mathrm{d} 1 \mathrm{bm} 00502 \mathrm{~b}$

PAL, K. et al. Sunlight sterilized, recyclable and super hydrophobic anti-COVID laser-induced graphene mask formulation for indelible usability. Journal of Molecular Structure, v. 1233, p. 130100, 2021. Available in: https://doi.org/10.1016/j.molstruc.2021.130100

PARDO-FIGUEREZ, M. et al. Antimicrobial nanofiber based filters for high filtration efficiency respirators. Nanomaterials, v. 11, n. 4, p. 1-17, 2021. Available in: https://doi.org/10.3390/nano11040900

PATIL, N. A. et al. Needleless electrospun phytochemicals encapsulated nanofibre based 3-ply biodegradable mask for combating COVID-19 pandemic. Chemical Engineering Journal, v. 416, p. 129152, 2021. Available in: https://doi.org/10.1016/j.cej.2021.129152

RAWAL, Amit. Multi-layered masks to combat COVID-19. Indian Journal of Medical Research, v. 152, n. 1-2, p. 9-11, 2020. Available in: https://dx.doi.org/10.4103\%2Fijmr.IJMR_2709_20

SHEN, H. et al. Development of Electrospun Nanofibrous Filters for Controlling Coronavirus Aerosols. Environmental Science and Technology Letters, v. 8, n. 7, p. 545-550, 2021. Available in: https://doi.org/10.1021/acs.estlett.1c00337

SINGH, S. et al. Carbon dot-polymer nanoporous membrane for recyclable sunlight-sterilized facemasks. Journal of Colloid and Interface Science, v. 592, p. 342-348, 2021. Available in: https://doi.org/ 10.1016/j.jcis.2021.02.049

SLAVIN, Y.N. et al. Metal nanoparticles: understanding the mechanisms behind antibacterial activity. Journal of Nanobiotechnology, v. 15, n. 1, p. 65, 2017. Available in: https://doi.org/10.1186/ s12951-017-0308-z

TIAN, C. et al. Antibacterial and antiviral N-halamine nanofibrous membranes with nanonet structure for bioprotective applications. Composites Communications, v. 24, 2020, p. 100668, 2021. Available in: https://doi.org/10.1016/j.coco.2021.100668 
TOLEDO, G.G. et al. Promising Nanostructured Materials against Enveloped Virus. Anais da Academia Brasileira de Ciências, v. 92, n. 4, 2020. Available in: https://doi.org/10.1590/ 00013765202020200718

VARAPRASAD, K. et al. Antibiotic copper oxide-curcumin nanomaterials for antibacterial applications. Journal of Molecular Liquids, v. 300, p. 112353, 2020. Available in: https://doi.org/10.1016/ j.molliq.2019.112353

VAZQUEZ-MUNOZ, R.; LOPEZ-RIBOT, J.L. Nanotechnology as an Alternative to Reduce the Spread of COVID-19. Challenges, v. 11, n. 2, p. 15, 2020. Available in: https://doi.org/10.3390/ challe11020015

WEISS, C. et al. Toward Nanotechnology-Enabled Approaches against the COVID-19 Pandemic. ACS Nano, v. 14, n. 6, p. 6383-6406, 2020. Available in: https://doi.org/10.1021/acsnano.0c03697

WORLD HEALTH ORGANIZATION - WHO. Advice on the use of masks in the context of COVID-19. Available in: https://apps.who.int/iris/handle/10665/332293. Access on: September 23, 2021.

WORLD HEALTH ORGANIZATION. WHO Coronavirus Disease (COVID-19) Dashboard. 2021. Available in: https://covid19.who.int/. Access on: September 23, 2021.

WU, F. et al. Visible-Light-Driven and Self-Hydrogen-Donated Nanofibers Enable Rapid-Deployable Antimicrobial Bioprotection. Small, v. 17, n. 12, p. 1-9, 2021. Available in: https://doi.org/10.1002/ smll.202100139

XIE, Y.Y. et al. Development and antibacterial activities of bacterial cellulose/graphene oxide-CuO nanocomposite films. Carbohydrate Polymers, v. 229, p. 115456, 2020. Available in: https://doi.org/ 10.1016/j.carbpol.2019.115456

ZHONG, H. et al. Plasmonic and Superhydrophobic Self-Decontaminating N95 Respirators. ACS Nano, v. 14, n. 7, p. 8846-8854, 2020. Available in: https://doi.org/10.1021/acsnano.0c03504 